\title{
Consuming Communities: The neighbourhood unit and the role of retail spaces on British housing estates, 1944-1958.
}

\begin{abstract}
This article challenges perceptions about the origins and objectives of 'neighbourhood unit principle' that emerged in 1944, by focusing on the location and purpose of shops. It argues that the positioning of retail spaces was central, but largely overlooked, to the socio-spatial schema that lay at the heart of the neighbourhood principle. Planners saw shops as a hub of face-to-face interaction, through which nebulous objectives like 'community spirit' might be engendered. However, planners did not account for the way that their need-based model of shopping might be undermined by the consumer habits of inhabitants and the changing objectives of retailers.
\end{abstract}

In 1944, advice emanating from both the state and town planners advocated the adoption of the 'neighbourhood unit' as a model for housing design in Britain. ${ }^{1}$ This conceptual template for suburban living formalised patterns of everyday sociability, leisure and consumption in the arrangement of units of 5,000 to 10,000 people and was applied widely in the decades following the war. ${ }^{2}$ Yet, by the 1960s the 'neighbourhood unit' was roundly condemned for its failure to produce the communities and neighbourliness its advocates had claimed it might,

\footnotetext{
${ }^{1}$ Ministry of Health (MoH), Design of Dwellings (London, 1944); Ministry of Health/Ministry of Works (MoH/MoW), Housing Manual 1944 (London, 1944), 1.

${ }^{2}$ Mark Clapson, Invincible Green Suburbs, Brave New Towns: Social Change and Urban Dispersal in Post-War England (Manchester, 1998); National Council of Social Services (NCSS), The Size and Social Structure of a Town (London, 1943), 8-9. On its popularity see: Peter Collison, 'Town planning and the neighbourhood unit concept', Public Administration, 32:4 (1954), 463-9. In 1951 19.2\% of county and borough planners in England and Wales used the neighbourhood principle in all designs, whilst 59.6\% used it in some. For the popularity in new towns: Andrew Homer, 'Creating new communities: the role of the neighbourhood unit in post-war British planning', Contemporary British History, 14:1 (2000), 63-80.
} 
and the 'neighbourhood principle' was touted as yet another example of planners' hubristic failure. $^{3}$

Sociologists such as Ruth Glass and John Mogey in the 1950s and historians Andrew Homer and Mark Clapson in the late 1990s have argued that diverse, non-local forms of association, a resistance to cross-class mixing and increasingly home-centred leisure pursuits undermined the territorially limited model of community represented by the neighbourhood. ${ }^{4}$ Clapson, Steven Fielding, Peter Thompson and Nick Tiratsoo have also shown how the neighbourhood unit's vision of a sociable, village-type life foundered on the failure to provide the promised community facilities and shops. ${ }^{5}$ There seems little to disagree with in these analyses; however, they only touch only lightly upon two further aspects of the neighbourhood unit. First, they largely neglect the underlying assumptions about the sociospatial mechanics of sociability that planners sought to invoke in their designs. Secondly, the role of consumer attitudes and the influence of retail capitalism in challenging planners' visions remain unexplored. Using case studies from Hull and Manchester, this article examines the ways in which inherently spatial constructions of community and sociability in the designs for retail facilities on post-war housing estates were challenged and undermined by patterns of consumption, the strength of retail capitalism and the efficacy of individual choice. Clapson and historian Ben Jones, using differing source materials, have both illustrated the diversity, heterogeneity and changeability of perceptions and feelings about

\footnotetext{
${ }^{3}$ Anthony Goss, 'Neighbourhood units in British new towns', The Town Planning Review, 32:1 (1961), 66-82; Lewis Mumford, 'The neighborhood and the neighborhood unit', The Town Planning Review, 24:4 (1954), 25670; Gillian Pitt, 'Neighbourhood planning in a new town', Town and Country Planning, 28:7 (1959), 263-5; Peter Willmott, 'Housing density and town design in a new town', Town Planning Review, 33:2 (1962), 124-6

${ }^{4}$ Clapson Invincible Green Suburbs, 175-86; Norman Dennis, 'The popularity of the neighbourhood community idea', in R. E. Pahl (ed.), Readings in Urban Sociology (Oxford, 1968), 74-92 (84-5); Ruth Glass, The Social Background of a Plan: A Study of Middlesbrough (London, 1948), 17-19; Peter H. Mann, 'The concept of neighborliness', American Journal of Sociology, 60:2 (1954), 163-8; John M. Mogey, Family and Neighbourhood: Two Studies of Oxford (Oxford, 1956). For discussion of the preference for home-centred leisure pursuits see: Judy Giles, Women, Identity and Private Life in Britain, 1900-50 (Basingstoke, 1995); Claire Langhamer, 'The meanings of home in postwar Britain', Journal of Contemporary History, 40:2 (2005), 341-62.

${ }^{5}$ Mark Clapson Working Class Suburbs: Social Change on an English Council Estate, 1930-2010 (Manchester, 2012); Steven Fielding, Peter Thompson and Nick Tiratsoo, "England Arise!" The Labour Party and Popular Politics in 1940s Britain (Manchester, 1997), 103-06.
} 
community on estates either side of the Second World War. ${ }^{6}$ The examination of the neighbourhood unit here thus functions as a lens through which to further demonstrate the difficulties of designing and applying rigid and homogenous models of community through planning schemes and housing layouts.

Early proponents of the 'neighbourhood principle' in 1920s presented it as a planning framework for determining the location of services, reducing traffic in residential areas and creating an aesthetically pleasing environment. ${ }^{7}$ However, the 'neighbourhood unit' that emerged in post-war Britain also reflected governmental anxieties about social cohesion on inter-war estates and planners sought to encourage desirable, yet abstract qualities such as 'neighbourliness' and 'community spirit' through the organisation of space, particularly through the positioning of retail facilities. ${ }^{8}$ By examining how inhabitants and retailers contested the space of the new estates, this article also demonstrates the complex processes at work in defining lived-in spaces, tackled by Douglas Robertson, Ian McIntosh and James Smyth. ${ }^{9}$ Planners' notions of shopping and shop location were conditioned by rigid calculations of need that did not account for the types of consumer tactics evidenced by historians like John Benson, Matthew Hilton and Ina Zweiniger-Bargielowska. ${ }^{10}$ Nor did they account for the power of retail capitalism — whether represented by independent shops or large chain retailers - to challenge the ability of corporations to control where and how

\footnotetext{
${ }^{6}$ Clapson, Working Class Suburbs; Ben Jones, 'The uses of nostalgia: autobiography, community publishing and working class neighbourhoods in post-war England', Cultural and Social History, 7:3 (2010), 355-74.

${ }^{7}$ Donald Leslie Johnson, 'Origin of the neighbourhood unit', Planning Perspectives, 17:3 (2002), 227-45; Dennis Keating and Norman Krumholz, 'Neighborhood planning', Journal of Planning Education and Research, 20:1 (2000), 111-14; Larry Lloyd Lawhon, 'The neighborhood unit: physical design or physical determinism?', Journal of Planning History, 8:2 (2009), 111-32.

${ }^{8}$ Clapson, Invincible Green Suburbs; Homer, 'Creating new communities'. On inter-war anxieties: Matthew Hollow, 'Governmentality on the Park Hill estate: the rationality of public housing', Urban History, $37: 1$ (2010), 117-35; Matthew Hollow, 'Suburban ideals on England's interwar council estates', Journal of the Garden History Society, 39:2 (2011), 203-17; Andrzej Olechnowicz, Working-Class Housing in England between the Wars: The Becontree Estate (Oxford, 1997).

${ }^{9}$ Douglas Robertson, Ian McIntosh, and James Smyth, 'Neighbourhood identity: the path dependency of class and place,' Housing, Theory and Society, 27:3 (2010), 258-73.

${ }^{10}$ John Benson, The Rise of Consumer Society in Britain, 1880-1980 (London, 1994); Matthew Hilton, Consumerism in Twentieth-Century Britain: The Search for a Historical Movement (Cambridge, 2003); Ina Zweiniger-Bargielowska, Austerity in Britain: Rationing, Controls, and Consumption, 1939-1955 (Oxford, 2000).
} 
shopping might take place. Nevertheless, the intention here is not to document or make arguments about the growth of consumerism amongst the working classes per se, nor to examine the experiences of patterns of consumption. Instead, the article aims to evidence the way that the inherently spatial tactics of retailers and shoppers alike, might undermine the models of community and social interaction envisaged in planners' visions.

The article starts by examining the specific features of the type of neighbourhood unit being proposed in 1944. The post-war neighbourhood unit demonstrates a difficult and complicated understanding of how 'sociability' and 'community' functioned, revealing concerns that influenced the adoption of the 'neighbourhood unit principle'. I argue that central to this version of the 'neighbourhood unit' was the location of shops and other facilities, the layout and quantity of which were determined by calculations of need through which planners framed a certain kind of citizen-shopper. In the second section I examine the records of local corporations to show how inflexible calculations of retail distribution were being challenged by the shopping habits of the inhabitants and the practices and preferences of retail capitalists.

\section{The British idea of the neighbourhood}

Architectural historian Nicholas Bullock has argued that 'in 1943 the concept of neighbourhood planning was new to England', adding that the recommendations in the Housing Manual 1944 'on housing layout [and] on the value of the 'neighbourhood unit' to planning ...were entirely new. ${ }^{11}$ Indeed, the type of neighbourhood unit proposed in the Dudley Report and other central government advice, has been taken by historians like Clapson and Homer as originating with the 1929 designs for New York by American planner Clarence Perry. Fielding et al have also pointed to the influence of planner Sir Charles Reilly on the post-war Labour government, arguing that the neighbourhood appealed to naïve Labour notions of cross class-mixing and wartime unity. ${ }^{12}$ These histories argue that the 'neighbourhood unit' was promoted by the British government in 1944 because it offered a spatial solution to concerns about the associative behaviours of the working classes, a concomitant lack of community and prejudices over the 'atomistic dormitory sprawl' of the

\footnotetext{
${ }^{11}$ Nicholas Bullock, Building the Post-War World: Modern Architecture and Reconstruction in Britain (London, 2002), $161 \& 164$.

${ }^{12}$ Fielding et al, "England Arise”, 103-105.
} 
inter-war estate. ${ }^{13}$ As Brad Beaven and John Griffiths' argue: 'the growth of remote residential suburbs heightened the anxiety that swathes of working-class communities were left to live and consume without appropriate civic guidance and instruction'. ${ }^{14}$ However, the 'neighbourhood unit' was not new to Britain in 1944, and it was explicitly part of the interwar plans for estates at Wythenshawe in Manchester and the London County Council's plans for the Becontree estate in the 1920s. ${ }^{15}$ Whilst relatively minor, the difference between the type of neighbourhood proposed in the 1920s and that adopted in 1944 is crucial to understanding the specific constructions of class, sociability and everyday life that were programmed into estate designs in post-war Britain.

Urban historians have demonstrated how anxieties over areas as diverse as public health, darkness, traffic, use of the countryside, homosexuality and juvenile delinquency have frequently been reproduced in spatial policies and legislation that framed the organisation of society and the organisation of space as one and the same project. ${ }^{16}$ In the same way, the appeal of the 'neighbourhood unit' to the British government lay in its status as a 'sociospatial schema' that proponents claimed to be a 'method of reinvigorating community feeling

\footnotetext{
${ }^{13}$ Clapson Invincible Green Suburbs, 29, 38 \& 39; Goss, 'Neighbourhood units in British new towns', 64; Homer, 'Creating new communities', 63-65.

${ }^{14}$ Brad Beaven and John Griffiths, 'Creating the exemplary citizen: the changing notion of citizenship in Britain 1870-1939', Contemporary British History, 22:2 (2008), 203-25 (205). General concerns about working-class association are noted by Tami Davis Biddle, 'British and American approaches to strategic bombing: their origins and implementation in the World War II combined bomber offensive,' Journal of Strategic Studies, 18:1 (1995), 91-144 (96); Gareth Stedman Jones, Outcast London: A Study in the Relationship Between Classes in
} Victorian Society (Harmondsworth, 1984), 290 and highlighted in housing design by Olechnowicz, WorkingClass Housing.

${ }^{15}$ Wesley Dougill, 'Wythenshawe: a modern satellite town', The Town Planning Review, 16:3 (1935), 209-15 (209); Olechnowicz, Working-Class Housing, 6. For more on Becontree see: Terence Young, Becontree and Dagenham: A Report Made for the Pilgrim Trust (Becontree, 1934).

${ }^{16}$ Ben Anderson, 'A liberal countryside? the Manchester Ramblers' Federation and the 'social readjustment' of urban citizens, 1929-1936', Urban History, 38:1 (2011), 84-102; Simon Gunn, 'The Buchanan Report, environment and the problem of traffic in 1960s Britain', Twentieth Century British History, 22:4 (2011), 52142; Patrick Joyce, The Rule of Freedom: Liberalism and the Modern City (London, 2003); Frank Mort, 'Fantasies of metropolitan life: planning London in the 1940s', Journal of British Studies, 43:1 (2004), 120-51; Lynda Nead, Victorian Babylon: People, Streets and Images in Nineteenth-Century London (London, 2000); Chris Otter, 'Making liberalism durable: vision and civility in the late Victorian city', Social History, 27:1 (2002), 1-15. 
at local level', eliminating the perceived anomie and isolation of inter-war suburbia. ${ }^{17}$ Study of the 'neighbourhood unit' thus carries the potential for the historian to explore constructions of perceived problems and patterns of daily life that were encoded in its design. Consequently, the exact details of the 'neighbourhood unit' that gained credence in 1944 deserve more careful attention than they have been given in the historiography. Architectural historian Nicholas Patricios has shown that Clarence Perry's original design for the neighbourhood was relatively silent on the ability of the 'neighbourhood unit' to develop social relations as anything but a peripheral feature of its design. ${ }^{18}$ The neighbourhood model proposed by Perry in 1929 was presented as a model for producing spacious, attractive housing layouts and convenient facilities and took its cues from planning theorists William Drummond, Raymond Unwin and Ebenezer Howard. ${ }^{19}$ Perry's 'neighbourhood unit' was a largely aesthetic 'reaction to the drab uniformity' of tightly-packed, nineteenth-century, gridpattern cities, which also reflected pragmatic considerations about integrating living spaces with patterns of increased automobile use. ${ }^{20}$

Perry acknowledged that chance encounters might encourage improved social life, also adding that local pride in the spacious and attractive neighbourhoods might engender voluntary participation in local politics or even uphold the moral and social values of the area. $^{21}$ Yet his model merely created the opportunities for face-to-face interaction, it did not rest upon the assumption that certain types of space would make those interactions inevitable. Perry's designs represented a flexible model in which any sort of space might produce opportunities for interaction, not a prescription for specific types of interactive space. In contrast, British advocates of the neighbourhood unit were convinced that the neighbourhoods they produced were 'that sort of physical environment which promotes

\footnotetext{
${ }^{17}$ Homer, 'Creating new communities', 64; Terence Lee, 'Urban neighbourhood as a socio-spatial schema', Human Relations, 21:3 (1968), 241-67 (243).

${ }^{18}$ Nicholas Patricios, 'The neighborhood concept: a retrospective of physical design and social interaction,' Journal of Architectural and Planning Research, 19:1 (2002), 70-90.

${ }^{19}$ Ebenezer Howard, Garden Cities of Tomorrow (Eastborne, 1985 [1902]); Clarence Arthur Perry, The Neighbourhood Unit (London 1998 [1929]); Raymond Unwin, Town Planning in Practice: An Introduction to the Art of Designing Cities and Suburbs (Princeton, 1996 [1909]). Perry is often cited as the originator of the neighbourhood unit, but work by Donald Leslie Johnson, 'Origin of the neighbourhood unit,' Planning Perspectives, 17:3 (2002), 227-45 suggests that William E. Drummond, part of Chicago's reformist and progressive milieu, originated neighbourhood planning theory in several publications between 1913-22.

${ }^{20}$ Lee, 'Urban Neighbourhood as a Socio-Spatial Schema', 243; Perry, The Neighbourhood Unit.

${ }^{21}$ Perry, The Neighbourhood Unit, 72-74.
} 
neighbourliness. ${ }^{22}$ Unlike Perry, they proposed a causal, deterministic relationship between spatial arrangement and the production of the elusive 'community spirit'.

British planners were promoting the 'neighbourhood unit' as an answer to a problem that Manchester City Surveyor and Engineer Rowland Nicholas outlined in 1945:

While Manchester can be justly proud of Wythenshawe we should recognise that the estate reflects the general trends in housing development since 1919 and suffers accordingly from a number of the defects...it has a somewhat anaemic social atmosphere - a lack of robust community life - attributable in part to its newness, but more particularly to the absence of good communal facilities. ${ }^{23}$

Nicholas, then, was representative of a wider dislike for inter-war housing amongst planners and policy makers implicit in famous planner (and author of Hull's post-war plans) Patrick Abercrombie's assertion that 'community grouping' was the only way to alleviate 'what might otherwise be interminable aggregations of housing'. ${ }^{24}$ Wythenshawe, though, had been produced as a series of socially-mixed, neighbourhood units of around 10,000 inhabitants since its inception in $1929 .^{25}$ Though Parker had been far less prescriptive or meticulous about the apportionment of shopping spaces then his post-war counterparts, when residents complained in 1944 that the estate 'suffered bitterly' from a lack of shops and communal facilities, the problem lay with the speed of construction, not with the amount of shops or community centres in the original plans. ${ }^{26}$

Despite the similarities between inter- and post-war designs, the perception amongst planners and local corporations alike appears to have been that estates like Wythenshawe suffered from poor 'social cohesion' (although where the evidence that this was either true or a problem comes from is not wholly clear) because they were designed incorrectly. In

\footnotetext{
${ }^{22}$ NCSS, The Size and Structure of a Town, 7.

${ }^{23}$ Rowland Nicholas, City of Manchester Plan (Norwich, 1945), 145.

${ }^{24}$ Patrick Abercrombie and J. H. Forshaw, County of London Plan (London, 1943), 28.

${ }^{25}$ Derick Deakin, Wythenshawe: The Story of a Garden City (Chichester, 1989), 45; Dougill, 'Wythenshawe', 209. For details on Dougill see his obituary in Town Planning Review, 19:3 (1943), 5-6.

${ }^{26}$ Manchester Guardian, 'The New Manchester', 6 Jan. 1944, 2; The files of the Wythenshawe Estate Special Committee detail a number of complaints about lack of facilities emanating from various residents groups throughout the 1940s, see: Greater Manchester County Records Office (GMCRO)/GB127/Council Minutes (CM)/Wythenshawe Estate Special Committee (WESC), Vols. 7-12, 15 Sep. 1939 - 1 Sep. 1950. In particular Harry Lloyd's statement to the committee GMCRO/GB127/CM/WESC/Vol. 9, 25 \& 24 Apr. 1945.
} 
addition, ministers like Lewis Silkin (the Minister of Town and Country Planning), advice emanating from the state in the Housing Manual 1944 and the prescriptions of influential publications like the National Council of Social Services' (NCSS) manual The Size and Social Structure of a Town, produced in 1943, all argued that inter-war estates had failed to produce communities because they been too homogenous in their socio-economic composition. In particular, they argued that the working classes lacked the civic leadership necessary to produce functioning communities when isolated in estates that did not feature a 'balanced' social mix. ${ }^{27}$

The production of a viable community thus rested on the twin pillars of mixed-class areas and the adequate provision of communal facilities. The idea of how these 'communities' might be made to work was given form in Nicholas' City of Manchester Plan:

The function of the neighbourhood is to supply the immediate needs of everyday living. The more self contained [sic] the structure, the greater will be its power to induce a sense of local patriotism and an interest in community life. Its development as a social entity will obviously be handicapped if it is split by physical barriers or by streams of traffic. $^{28}$

The suggestion here was unique to the type of neighbourhood design being proposed in postwar Britain: that the key to community success was isolating people within the estate from external social interaction. It was an idea also evident in Abercrombie's plans for Hull:

The community sense has largely been lost in our overgrown cities, though it still in part survives where neighbouring villages or outlying suburbs have been absorbed, but not completely engulfed. ${ }^{29}$

The language used in the extracts, perhaps unsurprisingly, indicates some confusion over what exactly community was. As social anthropologist Anthony Cohen has pointed out community is a seemingly intelligible word that continually defies easy definition. ${ }^{30}$ Hull's planners seem to have equated community with a cognitive experience, suggesting

\footnotetext{
${ }^{27}$ MH/MW, Housing Manual 1944, 11; MH, Design of Dwellings, 8; Lewis Silkin, 'Housing layout in theory and practice', Journal of the Royal Institute of British Architects, 55:10 (1948), 431-2 (431);NCSS, The Size and Social Structure of a Town, 3.

${ }^{28}$ Nicholas, City of Manchester Plan, 135.

${ }^{29}$ Patrick Abercrombie and Edward Lutyens, A Plan for the City and County of Kingston upon Hull (Hull, 1945), 55.

${ }^{30}$ Anthony Cohen, The Symbolic Construction of Community (London, 1985), 11.
} 
community was an emotional state to be experienced, rather than the pre-existing, but fixed set of activities that operate independently of the inhabitants suggested by Nicholas. Whilst this confusion is symptomatic of the difficulties of achieving such an ephemeral objective as community, what is crucial is that both planners were positing that communities could only exist where the neighbourhood was clearly delineated and geographically isolated from the city.

The notion that the neighbourhood should be cut off from the city was reinforced by the elimination of through traffic from the neighbourhood, with the road pattern dividing 'the city into a series of self contained [sic] precincts...thus residential neighbourhoods [were] insulated from industrial areas and separate identities are emphasised'. ${ }^{31}$ Whilst this sectioning of neighbourhoods with main roads appeared superficially to resemble Perry's plans for New York, his motives had been quite different. Indeed, his designs had grown in a pragmatic fashion from a project to produce a formula for the distribution of playgrounds in the New York area. ${ }^{32}$ This isolation of neighbourhood units within main roads, whilst similar in layout to the British planners' designs, was aimed at reducing the dangerous interactions between people and cars, not at producing an inward-looking community. ${ }^{33}$

As a reaction to the perception of the inter-war estates and an urban life that they felt was becoming too isolated and individualistic, the post-war planners of the neighbourhood appeared to be envisioning it as a village. Indeed, in the 1960s sociologist Peter Willmott and anthropologist Ronald Frankenberg would note that the idea of producing isolated villages had been one of the most extravagant and unrealistic of the goals of post-war British planning. ${ }^{34}$ Nevertheless, in the City of Manchester Plan Nicholas went as far as to state that:

A real community spirit still survives in the English village - in the companionship of the pub, in week-end cricket on the green and in the various activities of the village

\footnotetext{
${ }^{31}$ Hull History Centre (HHC)/CTCR/1.12.5 Report 17, 1 May 1944; Abercrombie \& Lutyens, A Plan for Kingston upon Hull, Plate IX.

${ }^{32}$ Perry, The Neighbourhood Unit, 27.

${ }^{33}$ Perry, The Neighbourhood Unit, 30.

${ }^{34}$ Ronald Frankenberg, Communities in Britain: Social Life in Town and Country (Harmondsworth, 1969), 197; Peter Willmott 'Social research and new communities', Journal of the American Institute of Planners, 33:6, (1967), 387-98 (390).
} 
organisations. The neighbourhood unit is a modern urbanised version of the traditional village and the counterpart of the village green is the neighbourhood centre. ${ }^{35}$

The appeal of the semi-mythological English village against the vast and impersonal city evokes Ferdinand Tönnies' concept of Gemeinschaft (community), a social form characterised by emotional cohesion, continuity, locality and kinship. ${ }^{36}$ However, it is doubtful that the gemeinschaftliche 'Deep England' that Nicholas described existed outside his mind, war-time propaganda posters and Thomas Hardy novels. ${ }^{37}$ Nevertheless, these suburban village communities were being proposed for new neighbourhoods across Britain and, though Abercrombie was insistent that neighbourhoods would be part of a wellconnected 'fusion of local and city life', the aims of the British 'neighbourhood unit' appeared only to focus the lives of the inhabitants inwards.

As planner Donald Foley observed in 1960, the neighbourhood principle carried 'a strong emotional appeal for those convinced that the city is too impersonal and complex, for it suggests the creation of small social units in the place of undifferentiated bigness. ${ }^{38}$ In the neighbourhood unit British planners were challenging this modern 'bigness' with highlymodern solutions to the avowedly modern problem of suburban anomie, yet also attempting to produce forms and interactions they conceived of as essentially pre-modern. The evidence then is suggestive of a wider split in the national selfhood of Britain at the end of the Second World War: with one eye looking to a modern, planned future, but with the other gazing longingly at a disappearing, semi-mythical past, represented in the 'Deep England' propaganda examined by Angus Calder. ${ }^{39}$ Deep-seated inter-war prejudices about suburbia and working-class association were thus being spatialised in plans for neighbourhoods alongside this desire to preserve an imagined local community that had been valorised during the war as a deeply desirable and uniquely British quality.

\footnotetext{
${ }^{35}$ Nicholas, City of Manchester Plan, 135.

${ }^{36}$ Ferdinand Tönnies, José Harris, and Margaret Hollis, Community and Civil Society (Cambridge, 2001).

${ }^{37}$ Angus Calder, The Myth of the Blitz, (London, 1992), 180-209.

${ }^{38}$ Donald L. Foley, 'British town planning: one ideology or three?', The British Journal of Sociology, 11:3 (1960), 211-31 (223).

${ }^{39}$ Calder, The Myth of the Blitz; Becky Conekin, “"Here is the modern world itself”: the Festival of Britain's representations of the future,' in Becky Conekin, Frank Mort and Chris Waters (eds.), Moments of Modernity: Reconstructing Britain, 1945-1964 (London, 1999), 228-46 (245).
} 
Isolation was designed to force inhabitants to look within the estate to accommodate their needs. However, the mechanisms imagined for forming community were more complex than mere geographical isolation. As the City of Manchester Plan proposed, 'the function of the neighbourhood [was] to supply the immediate needs of everyday living'. ${ }^{40}$ It was thus through a mapping of everyday needs and movements that planners believed that the face-toface interactions necessary to foster community, sociability and neighbourliness might be generated. The way they proposed to do this was by creating a hub of daily life that was impossible to avoid. As editor Wesley Dougill had argued in the Town Planning Review in 1935, the main cleft amongst advocates of the 'neighbourhood unit' had been the location of the shops. ${ }^{41}$ The shops were on the outskirts of the units on major roads in Perry's original schema for the 'neighbourhood unit' and in Parkers' original designs for Wythenshawe. ${ }^{42}$ This location was repeated on the 1930s Garden City type neighbourhoods like Hull's Derringham Bank and North Hull, conforming to shopkeepers' preference to be situated where passing trade and several overlapping populated areas might generate the greatest business. ${ }^{43}$ In contrast, the designs for Hull and Manchester's new estates in the two cities post-war plans show the shops placed at the centre of the units. ${ }^{44}$

Hull's Bilton Grange extension, approved on 1 May 1944 by the Hull Housing Committee, and Anlaby Road scheme both had an initial layout which included a community centre consisting of as many as 30 shops and offices, a school and other essential facilities at the centre of the development. ${ }^{45}$ The centre of each neighbourhood was envisioned as the site of a frequent, if not daily visit - shops for food and consumables and the school to deposit and collect children - where face-to-face encounters between the local populace might take place. Empathies, camaraderie and commonalities of interests would emerge as a result of regular interactions, which in time might transfer to community centres and public houses or coalesce into gardening clubs, tenants associations or football teams. Functional provision of services and facilities, formation of identity and the complexities of social interaction thus appear to be have been subsumed into an opaque, magic box from which communities would

\footnotetext{
${ }^{40}$ Nicholas, City of Manchester Plan, 135.

${ }^{41}$ Dougill, 'Wythenshawe', 209.

${ }^{42}$ Dougill, 'Wythenshawe', 212; Perry, The Neighbourhood Unit.

${ }^{43}$ Dougill, 'Wythenshawe', 212.

${ }^{44}$ Lutyens \& Abercrombie, Plan for Kingston upon Hull, Plate XLI; Nicholas, City of Manchester Plan, Plate 52.
}

${ }^{45}$ HHC/CTCR/1.12.5, File 24, Report 17, 1 May 1944: HHC/CTAH/2/Box 2020, undated, but circa Apr. 1945. 
subsequently emerge. Service provision, particularly shops, was therefore at the heart of how the 'neighbourhood unit' functioned spatially. Isolation from alterative places to shop was designed to produce a very specific and rigidly defined set of practices and movements.

\section{Where the politics of necessity meets consumerism}

That these rigid prescriptions inscribed in the built environment failed to have the desired result is now an accepted part of the historiography. For example planning historian Murray Stewart argued that:

...there remains little validity in the concept of an urban neighbourhood, or a local community, seen as a self-contained unit comprising jobs, shops, recreational and cultural facilities, delimited by physical boundaries and functioning in terms of the spatial arrangement of the buildings. ${ }^{46}$

Other scholarship, particularly Clapson and Willmott's work, argues that planners' overestimated the effectiveness of layout and the built environment in influencing the geographical dimensions of people's associative lives. ${ }^{47}$ The prominence afforded to the local in constructions of recreation and sociability was only exacerbated by increasing affluence throughout the 1950s. Higher incomes facilitated the mass consumption of home-centred forms of entertainment, particularly radio and television, whilst simultaneously providing greater personal mobility through increased car ownership. ${ }^{48}$ Yet the location in which leisure activities took place was not the only metric upon which the framers of neighbourhood policy had based their plans. They had also anticipated a multitude of face to face contacts in the carrying out of the mundane and everyday activities involved in regular visits to the shops or collecting children from school, which were significant, unavoidable and, above all, frequent, perhaps daily events.

\footnotetext{
${ }^{46}$ Murray Stewart, The City: The Problems of Planning (Harmondsworth, 1972), 32.

${ }^{47}$ For a general critique of the assumptions behind the neighbourhood unit see: Herbert Gans, The Urban Villagers (New York, 1962); Jon Lang, Creating Architectural Theory: The Role of the Behavioural Sciences in Environmental Design (New York, 1987), 101; Christopher Silver, 'Neighborhood planning in historical perspective,' Journal of the American Planning Association, 51:2 (1985), 161-74. Clapson, Invincible Green Suburbs, 156-95; Willmott 'Social research and new communities', 390; Peter Willmott, 'Housing density and town design in a new town,' Town Planning Review, 33:2 (1962), 115-27.

${ }^{48}$ Clapson, Invincible Green Suburbs; Frankenberg, Communities in Britain, 233-4; Glass, The Social Background of a Plan, 17-19; Homer, 'Creating new communities', 77-8; Mogey, Family and Neighbourhood; Olechnowicz, Working-Class Housing; Peter Willmott, Community Initiatives: Patterns and Prospects (London, 1989), 85-9.
} 
The importance of shops to inhabitant's lives, especially in an age before massownership of refrigerators, is borne out by the amount of ink devoted to complaints about the lack of shops in the minutes of Manchester's Wythenshawe Estate Special Committee (WESC). Harry Lloyd, the chairman of Wythenshawe's local tenants organisations the Wythenshawe Community Council (WCC) and the Wythenshawe Federal Council (WFC), detailing the proceedings of a meeting at Benchill School organised by the WCC on 15 February 1946, reported that:

...this meeting of approximately 400 of the public of Wythenshawe protests in the strongest possible terms at the dilatory attitude of the Wythenshawe Estate Committee in not providing sufficient shops and calls upon it to arrange an early public meeting in Wythenshawe for them to attend and give an explanation of their future intention. ${ }^{49}$

The following May, a Town Clerk's Report to same committee also pointed out that the inadequacy of shopping facilities was a constant source of problems on the Wythenshawe estate. ${ }^{50}$ Records from the Hull Corporation Housing Committee also indicate that in 1949, as tenants began moving in to new estates at Bricknell Ave, Priory Rd, Southcoates Lane and Bellfield Ave/Salthouse Road, serious concerns remained about the availability of shopping facilities. In several instances shops were unacceptable distances from dwellings, being outside of the boundaries stipulated in the Corporation's principles of estate design. ${ }^{51}$ The limits of materials and man power available meant that work would not commence on any of the, up till that point, empty sites for shops before summer of 1950, despite the Ministry of Health's view that there was a severe 'consumer need' for shops on each of the estates. ${ }^{52}$

Each neighbourhood unit's provision of shops was based on a number of defined criteria. Shops would be no more than a certain distance, usually a third of a mile, from any house in the neighbourhood and the number and types of shops would be defined by carefully-calculated estimates of the projected intake of foods and consumables each

\footnotetext{
${ }^{49}$ GMCRO/CM/WESC, Vol. 9, 366, ‘Wythenshawe Estate — Shops’, 20 Feb. 1946.

${ }^{50}$ GMCRO/CM/Housing Committee (HC), Vol.28, 168, 'Provision of Shopping Facilities', 22 May 1946.

${ }^{51}$ For example see: HHC/CTAH/2/Box 2187/file 64, 'Proposed Provision of Blocks of Shops', 8 Aug. 1949.

${ }^{52}$ Various Correspondence, HHC/CTAH/2/Box 2187/file 64, 8-19 Aug. 1949.
} 
household on the estate would need. ${ }^{53}$ The local corporations maintained control of what could be sold where by licensing only what they felt fitted into the overall scheme of the plan. So, in 1942 when the Co-operative Society based at Wythenshawe's Brownley Green, applied to the City Surveyor for extra premises to deal with 'upwards of 1500' family registrations for rationed commodities they were refused. Instead, they split their business into different usages and moved butchery to a new site, making the decisions that it was easier to have the Corporation licence two shops with different functions rather than one larger shop. ${ }^{54}$

The nature of what inhabitants wanted to buy and how far they were prepared to go was rather at odds with the Corporation's views on what people 'needed' even during periods of rationing. Hilton's history of British consumerism argues that throughout the 1940s, even before the increasing affluence of the 1950s made 'the politics of necessity' a thing of the past, the 'consuming desires', not just the needs, of the people had to be considered by policy makers. ${ }^{55}$ Neighbourhood design and local policy do not appear to have accounted for the exercising of consumer desires by the people of the estates though. As historian Ina Zweiniger-Bargielowska demonstrates, consumption strategies amongst women, even during the war, were far more complex and unpredictable than any government might have been able to plan for. ${ }^{56}$ The following examples suggest how these strategies undermined the neighbourhood's conflation of social interaction with shopping habits.

In 1944 the Manchester Town Clerk's report indicated that on 22 February the Wythenshawe Estate Special Committee had instructed him to take action against Mr J.W. Perry, 112 Sale Rd, Northenden, a Post Office owner who was selling stationery, an action beyond the remit of his license. Several letters from local residents were received in support of Perry continuing to sell extra stationery and a petition with 1032 signatures (seemingly initiated by Perry himself) was also received. ${ }^{57}$ The Corporation, despite the petition, insisted

\footnotetext{
${ }^{53}$ Rowland Nicholas, Manchester and District Regional Planning Proposal (Norwich, 1945), 44-6;

GMCRO/CM/WESC, Vol. 10, 102 'Shopping Facilities', 25 Nov. 1946; HHC/CTAH/2/Box 2187/file 64, 'Proposed Provision of Blocks of Shops', 8 Aug.1949.

${ }^{54}$ GMCRO/CM/WESC, Vol. 8, 7-45, various correspondence, 24 Feb. 1942-Jul. 1942.

${ }^{55}$ Hilton, Consumerism in $20^{\text {th }}$-Century Britain, 137.

${ }^{56}$ Zweiniger-Bargielowska, Austerity in Britain.

${ }^{57}$ GMCRO/CM/WESC, Vol.8, 424, 'J.W. Perry, 112 Sale Rd, Northenden', 19 Dec. 1944.
} 
that the same items were available at 116 Sale $\mathrm{Rd}$ in a newsagent and there would be no extension of Perry's licence, to which they received the following reply:

To put the matter very mildly, your reply to the petition has given no satisfaction whatever, and has created a feeling of thorough indignation... They ask why their neighbours at Northenden (non-Corporation tenants) enjoy the privilege of being able to obtain their stationary [sic] requirements in full... whilst they, as Corporation tenants are restricted...and have to travel to Northenden...it is the duty of the Wythenshawe Committee to serve the public of Wythenshawe, not to rule them... They require more facilities and less restrictions [original emphases]. ${ }^{58}$

Sadly for Perry his claims achieved little and the Corporation remained steadfast in their decision.

The records of Mr Perry's disagreement with the Corporation reveal him motivating a argument that stressed the equality of corporation tenants to consume what they wanted on a par with private tenants and owners. This assertion of the right to consume over merely the right to purchase for necessity - presented here by Perry as an act of political contestation - echoes observations by historians Charlotte Wildman and Selina Todd who point to burgeoning consumer cultures in the inter-war period that functioned as methods of blurring class boundaries and negotiating desirable selfhoods. ${ }^{59}$ Here, strategies of where to buy certain products also contested what might happen in a given space and challenged the spatial strategies of the planners. Geographers Michelle Lowe and Joel Garreau, in their work on out-of-town shopping malls, have shown how, by attracting customers to new forms of retail, retailers can contest the political and spatial boundaries of traditional urban forms like towns, neighbourhoods and cities. ${ }^{60}$ Perry's apparent concern for the public was probably concern for his own pocket, but his arguments show how even small retailers could attempt to bend the spatial discipline of the planners to their will. Planners had based their plans for neighbourhoods around regular trips to certain shops at the centre of the development, yet

\footnotetext{
${ }^{58}$ GMCRO/CM/WESC, Vol.9, 54-55, 'Letter from J.W. Perry', 20 Mar. 1945.

${ }^{59}$ Selina Todd, 'Poverty and aspiration: young women's entry to employment in inter-war England', Twentieth Century British History, 15:2 (2004), 119-42; Charlotte Wildman, 'The spectacle of interwar Manchester and Liverpool: urban fantasies, consumer cultures and gendered identities', University of Manchester Ph.D. Thesis, 2007, 137-67.

${ }^{60}$ Joel Garreau, Edge City: Life on the New Frontier (New York, 1991); Michelle S. Lowe, 'Britain's regional shopping centres: new urban forms?', Urban Studies, 37:2 (2000), 261-74.
} 
Perry's letter implied that the customers were willing to travel for choice, price or the convenience of buying everything in one place. As geographers William Clark, Gerard Rushton and R.A. Day have argued the distance to a shop is rarely the only determinant in the process of selecting where to shop, with greater variety of products, value and perceptions of quality often leading individuals to consider longer journeys worthwhile. ${ }^{61}$

Many of Perry's objections echo a wider debate taking place at a local and, to an extent, national governmental level in the years following the war. In 1944 the Retail Advisory Committee on Town Planning (RACTP), an ad hoc organisation formed at the behest of the Ministry of Town and Country Planning and consisting of various members of Chambers of Trade, Retailers Associations and Co-operative Societies, issued a booklet named The Planning of Shopping Areas. ${ }^{62}$ In it they laid down several guidelines which directly challenged the corporations' models of retail. They began by questioning the very basis on which planners had calculated the numbers of shops:

It is obviously necessary that the planner should know how many shops and stores will be required in each centre... Some guidance can of course be obtained from records of actual experience...But the outstanding feature of such records is the wide variations which they reveal in the number of shops in proportion to population...It is not possible to estimate precisely the shopping needs of a particular community, still less forecast how they are likely to change in future years. The planner must therefore avoid committing himself irrevocably to rigid assumptions on the subject. ${ }^{63}$

Whilst their advice also warned against trying to allocate precise numbers of each shop, where the RACTP did give advice on numbers their figures suggested densities between two to four times greater than had been allowed for by planners. ${ }^{64}$ Corporations, it appears, were basing their estimations of how shopping facilities should be provided on a model of basic necessity, whilst banking on their own ability to exercise control of small, independent

\footnotetext{
${ }^{61}$ William Clark and Gerard Rushton, 'Models of intra-urban consumer behaviour and their implications for central place theory', Economic Geography, 46:3 (1970), 486-97; R. A. Day, 'Consumer shopping behaviour in a planned urban environment,' Tijdschrift voor Economische en Sociale Geografie, 64:2 (1973), 77-85.

${ }^{62}$ Retailers' Advisory Committee on Town Planning (RACTP), The Planning of Shopping Areas: Setting out the Principles which should be Followed in Planning Shopping Areas (London, 1944).

${ }^{63}$ RACTP, The Planning of Shopping Areas, 4.

${ }^{64}$ RACTP, The Planning of Shopping Areas, 4-11; Nicholas, Manchester and District Regional Planning Proposal, 37.
} 
retailers. Manchester's Housing Committee records indicate that opportunities to let shops before and after the war were continually applied for by many more aspiring shopkeepers than there were retail spaces and corporations maintained a strict control of what might be sold where. ${ }^{65}$

The model of necessity that was intrinsic to the distribution of shops on the new estates relied on the maintenance of a spatial model of shopping behaviours that was increasingly challenged by consumer desires, but also by retailers of differing sizes. In 1949 plans were drawn up for the main shopping centre (as part of the community centre) on Hull's Longhill Estate, the building of which commenced shortly after. Yet by 1954, despite the ongoing development of houses, there were still no premises available for shops. The city architect stated that 'as there are already a considerable number of dwellings completed and occupied on this estate, and many others in the course of construction' the Housing committee were anxious to proceed with the building of this main shopping centre as soon as possible. ${ }^{66}$

The Housing Committee subsequently offered a site on the estate in a letter to Woolworth's on 30 December $1954 .^{67}$ The response from Woolworth's, though, was less than enthusiastic and reflects the increasing power of chain stores and large retailers to discipline space in opposition to planners' visions of daily life. In a letter, Woolworth's criticised the development of Hull's largest estates:

We regret that we could not contemplate being represented in a shopping centre with only ten other lock-up shops as an attraction; this shopping centre being proposed by you is less than half the size of the Bilton Grange Estate, where we did express our view that you had provided for too few shops. ${ }^{68}$

Woolworth's also suggested that the design of shops available was not suitable for the type of store they required; going so far as to include photographs of how they felt Woolworth's

\footnotetext{
${ }^{65}$ GMCRO/CM/HC, Vol.29, 25-9,various correspondence, 30 Jul. 1947-7 Nov. 1947. On the White Moss Estate in Blackley, Manchester in 1947 new butchers' and grocers' were allocated. Complaints were received from several existing owners' solicitors protesting the decision to provide additional butchers and grocers in an already 'saturated' market; 15 applications were received to fill two shops. A pattern repeated throughout the 1930s and 1940s, see: GMCRO/CM/HC/Vol.25-30 for multiple examples.

${ }^{66}$ HHC/CTAH 2/Box 2173/File 100, 'Longhill Estate Shopping Centre', 30 Dec. 1954.

${ }^{67}$ HHC/CTAH 2/Box 2173/File 100, 'Longhill Estate Shopping Centre', 30 Dec. 1954.

${ }^{68}$ HHC/CTAH 2/Box 2173/File 100, Letter to Hull City Architect from F.W. Woolworth and Co. Limited, 9 Feb. 1955.
} 
frontages should look. In doing so, Woolworth's imposed their own vision of how the process of shopping functioned, the type of surroundings suitable for retail and what shoppers wanted, which were antithetical to both the physical and conceptual models of planners. In 1954 historian James Jefferys noted that by 1939 half of the grocery retail in Britain was in the hands of large-scale retailers and Woolworth's were representative of the growing power significant market share was allowing. ${ }^{69}$ Woolworth's approach appears to be representative of strategies of other inter-war chain retailers in Britain and Europe, who Andrew Alexander and Risto Laulajainen demonstrate pursued aggressive spatial strategies to obtain the most advantageous locations to attract custom and challenge smaller retailers. ${ }^{70}$ Woolworth's believed that if the shopping centre was not sufficiently large it would not attract shoppers to justify their outlay on the shop. By rejecting the opportunity to set up a shop, Woolworth's marked an important shift in the power of local government to influence how retail was planned. This hinted at a changing relationship that, by the 1980s, would become so asymmetrical that the power of retailers to dictate where consumption occurred meant essential items were no longer available near social housing projects. $^{71}$

The 1944 advice from RACTP suggested that shopping centres needed to be a sufficient size and preferably on a street so that people might enjoy the activity of shopping, rather than it merely being a functional activity. ${ }^{72}$ Woolworth's had been at the forefront of variety chain retailing from the 1930s (large self-service shops where consumers could look round without pressure to buy a large variety of goods), which furthermore stressed shopping as a semileisure activity. ${ }^{73}$ Even with increasing affluence on the estates, it was unlikely that

\footnotetext{
${ }^{69}$ James B. Jefferys, Retail Trading in Britain, 1850-1950 (Cambridge, 1954).

${ }^{70}$ Andrew Alexander, 'Retailing and consumption: evidence from war time Britain,' The International Review of Retail, Distribution and Consumer Research, 12:1 (2002), 39-57 (45); Risto Laulajainen and Lars-Erik
} Gadde, 'Locational avoidance: a case study of three Swedish retail chains,' Regional Studies, 20:2 (1986), 13140 .

${ }^{71}$ Rosemary Bromley and Colin Thomas, 'The impact of out-of-centre retailing,' in Rosemary Bromley and Colin Thomas (eds.), Retail Change: Contemporary Issues (London, 1993), 126-50; Cliff Guy, 'Corporate strategies in food retailing and their local impacts: a case study of Cardiff,' Environment and Planning A, 28:9 (1996), 1575-602; Neil Wrigley, Cliff Guy, and Michelle Lowe, 'Urban regeneration, social inclusion and large store development: the Seacroft development in context,' Urban Studies, 39:11 (2002), 2101-14.

${ }^{72}$ RACTP, The Planning of Shopping Areas.

${ }^{73}$ Jefferys, Retail Trading in Britain, 69-70. For an overview of the expansion of shopping as a leisure activity see: Peter Newby, 'Shopping as leisure', in Bromley and Thomas (eds.), Retail Change:, 208-28. 
Woolworth's models of consumer behaviour matched the model of need-based shopping that the Corporation favoured. Woolworth's added:

We do not... wish to dictate to you how to provide for the shopping needs of your Estate, but it is interesting to note that in a Nottingham suburb where we are going to be represented, the Corporation have based the number of shops on one per two hundred persons. $^{74}$

They went on to add that Birmingham Corporation was using a similar figure, implying that Woolworth's felt there would be too few people to use the shop to make it viable as a business.

Ultimately, in November 1958, two shops opened at Longhill providing only a fifth of the retail outlets envisioned in the original plans. ${ }^{75}$ It was not corporation tardiness or lack of building materials that had left the estate without facilities, but the intersection of competing definitions of how and what retail was for. The actions of Woolworth's were symptomatic of the meeting of the spatial politics of necessity with the expanding realm of consumerism. Gareth Shaw, Louise Curth, and Andrew Alexander all suggest that up until 1954 food control legislation and prohibitive construction policies prevented any significant developments in the areas of everyday grocery retail that would come to be dominated by supermarkets. ${ }^{76}$ Yet, it is apparent from the evidence here that even during the period of rationing consumer behaviours and an active antipathy amongst the retail trade towards plans for post-war estates were already undermining the model of shopping and sociability proposed by planners.

\section{Conclusion}

Despite the claims of post-war planners, the 'neighbourhood unit principle' was not new to Britain in 1944, having been used sporadically in the inter-war period. However, the version of the unit adopted featured telling revisions to Perry's 1929 model. Anxieties over atomistic suburbs, working-class association and the loss of a mythologised, village atmosphere were all expressed in the vision of the neighbourhood produced in 1944. This vision displayed a

\footnotetext{
${ }^{74}$ HHC/CTAH/2/Box 2173/File 100, Letter to Hull City Architect from F.W. Woolworth and Co Limited, 9 Feb. 1955.

${ }^{75}$ HHC/CTAH/2/Box 2173/File 100, 'Longhill Estate Main Shopping Centre', 21 Sep. 1956 \& 15 Nov. 1958.

${ }^{76}$ Gareth Shaw, Louise Curth, and Andrew Alexander, 'Selling self-service and the supermarket: the americanisation of food retailing in Britain, 1945-60', Business History, 46:4 (2004), 568-82.
} 
rather confused and fractured notion of modernity that looked back to a never-existent community past and attempted to recreate this through spatial control. Planners sought to isolate neighbourhoods from the city and advanced a suburban lifestyle that relied on everyday social interaction to produce communities. The isolation and inward-looking nature of the neighbourhood unit meant centralised service provision that might encourage frequent, face-to-face meetings — particularly around shops — was a fundamental aspect of their model of social interaction.

This template for face-to-face interaction was spatially underpinned by limited and rigid notions of movement and shopping, which in the post-war period proved unsustainable, if they ever had been at all. Even during the period of rationing, which ended in 1954, the tactics of shoppers showed signs of being far more complex than either the models of movement or the notions of necessity that planners had based their neighbourhood designs upon. ${ }^{77}$ Although not explored here, further studies of the role of retail space in the post-war neighbourhoods might productively use personal testimony - in the manner produced by Jones or Ann Hughes and Karen Hunt in similar environments - to better understand the development of these consumer behaviours. ${ }^{78}$ Retailers too appear to have believed that the shopping centres of the new estates did not match up to the desires or habits of inhabitants. Nor did the locations and layout of the shopping centres encourage the types of shopping and shopper that they wanted to produce. In response to the design of estates retailers actively disrupted corporations' spatial strategies through the deployment of tactics that confounded the need-based models of shopping.

\footnotetext{
${ }^{77}$ Ina Zweiniger-Bargielowska, 'Rationing Austerity and the Conservative Party Recovery After 1945', Historical Journal, 37:1 (1994), 173-97.

${ }^{78}$ Ann Hughes and Karen Hunt, ‘A culture transformed? Women's lives in Wythenshawe in the 1930s' in Andrew Davies and Steven Fielding (eds.), Workers Worlds: Cultures and Communities in Manchester and Salford, 1880-1939 (Manchester, 1992) , 74-101; Jones, 'The uses of nostalgia', 355-74.
} 